\title{
Investigating the temporal trends in PAH, PCB and OCP concentrations in Hartbeespoort Dam, South Africa, using semipermeable membrane devices (SPMDs)
}

\author{
Robert Amdany', Luke Chimuka1*, Ewa Cukrowska', Petr Kukučka², Jiří Kohoutek² and Branislav Vrana² \\ 'School of Chemistry, University of the Witwatersrand, P/Bag 3, WITS, Johannesburg 2050, South Africa \\ ${ }^{2}$ Research Centre for Toxic Compounds in the Environment (RECETOX), Masaryk University, Kamenice 573/5, CZ-625 00 Brno, Czech Republic
}

\begin{abstract}
The seasonal variability of persistent organic pollutants in Hartbeespoort Dam, South Africa, was investigated using semipermeable membrane devices (SPMDs) as passive samplers. Freely dissolved waterborne polycyclic aromatic hydrocarbons (PAHs), polychlorinated biphenyls (PCBs) and organochlorine pesticides (OCPs) were sampled to investigate seasonal changes in their concentrations. Exposure of the passive samplers was done for 14 days at the same sampling site in each of the four seasons of the year, in 2011. The SPMD-derived analyte amounts enabled the calculation of time-weighted averages of free dissolved waterborne levels of the contaminants. Concentrations ranged from $30.0 \mathrm{ng} \cdot \ell^{-1}$ to $51.5 \mathrm{ng} \cdot \ell^{-1}$ for PAHs, $38 \mathrm{pg} \ell^{-1}$ to $150 \mathrm{pg} \cdot \ell^{-1}$ for PCBs, 9.2 to $10.4 \mathrm{ng} \cdot \ell^{-1}$ for $\mathrm{HCHs}$ and 0.3 to $0.8 \mathrm{ng} \cdot \ell^{-1}$ for DDTs, respectively. It was also noted that the winter season generally exhibited higher contaminant concentrations for most compounds studied, which likely reflects the seasonality of their atmospheric deposition. An attempt was also made to identify possible sources of PAH contaminants in the dam by examining PAH ratios. These diagnostic ratios were inclined towards pyrogenic sources of pollution, except for the winter season where both pyrogenic and petrogenic sources likely contribute to the contamination pattern.
\end{abstract}

Keywords: Hartbeespoort dam, persistent organic pollutants, semipermeable membrane devices, waterdissolved concentrations, temporal trends.

\section{INTRODUCTION}

Globally, huge quantities of organic pollutants, including persistent organic pollutants (POPs), are released into the environment. Due to their ubiquitous nature, hydrophobic organic compounds such as polycyclic aromatic hydrocarbons (PAHs), polychlorinated biphenyls (PCBs) and organochlorine pesticides (OCPs) have been identified as environmental contaminants in almost every compartment of the global system (ATSDR, 2009). As byproducts of incomplete combustion of organic compounds, pyrosynthesis or pyrolysis of hydrocarbons, PAHs are released to the environment by both natural and anthropogenic sources (Levinson et al., 2008). PAHs may also reach water systems through oil spills and direct industrial effluent discharges. PCBs and OCPs, on the other hand, are POPs of anthropogenic origin. Chemically stable, strongly lipophilic and considerably toxic, OCPs have slow degradation rates and tend to bioaccumulate in lipid-rich tissues (Tiemann, 2008) of living organisms. PAHs, PCBs and OCPs are of particular interest because of their potential toxicity, carcinogenicity, possible mutagenicity as well as tendency to bioaccumulate. They are present in the aquatic environment both as truly dissolved and particle-bound. The easily bioavailable fraction, which corresponds to the free dissolved fraction, is of primary interest for risk assessment (Sabaliunas and Sodergren, 1997). It is generally assumed that particle- and colloid-bound compounds

To whom all correspondence should be addressed.

Tel: +27 11 717-6703; e-mail: luke.chimuka@wits.ac.za Received 9 May 2013; accepted in revised form 6 May 2014. cannot cross biological membranes, bioconcentrate and cause biological effects (Landrum et al., 1985). The concentration of freely-dissolved POPs in the water column is directly proportional to their chemical activity and fugacity in the water phase and is an important parameter in modelling their fate in the environment (Mayer et al., 2003).

Due to their characteristically high hydrophobicity and very low solubility in water, these compounds are adsorbed onto finely-dispersed colloids and particulates. Thus, their free dissolved concentrations in water are often several orders of magnitude lower than the total concentrations. Indeed, the water-dissolved concentrations are generally low (ng. $\ell^{-1}$ to $\mathrm{pg} \cdot \ell^{-1}$ range) and insufficient for reliable quantitative chemical analysis by conventional methods. Consequently, proper analysis of free dissolved PAHs and PCBs in natural water is not easy and many sampling problems are encountered.

A viable alternative to a grab sampling approach is to use passive samplers. These devices usually combine sampling, selective analyte isolation, pre-concentration and, in some cases, speciation preservation, in one step (Vrana et al., 2005). The long accumulation period by the samplers allows for detection of very low concentrations of target analytes (Sabaliunas and Sodergren, 1997), which would otherwise be impractical to achieve. By providing time-weighted average (TWA) values that take into account episodic fluctuations in pollutant concentrations, these devices are better suited for long-term monitoring of contaminants in an environmental compartment (Kot et al., 2000). Among passive sampler devices (PSDs), semipermeable membrane devices (SPMDs) have been widely applied to estimate the concentrations of hydrophobic contaminants in the water phase (Huckins et al. 2006; Verweij et al., 2004; Huckins 
et al., 1993). These passive samplers are composed of a trioleinreceiving phase for contaminant accumulation enclosed in a low-density polyethene membrane (LDPE). Contaminant residues sequestered by the SPMDs represent an estimation of the dissolved or readily bioavailable concentration of hydrophobic contaminants in water, which is not provided by most analytical approaches (Vrana et al., 2001). Sampling rates $(R)$ for highly hydrophobic compounds are influenced by the environment's hydrodynamic conditions (Booij et al., 2007), such as water turbulence, biofouling and temperature at the sampling site. Through incorporation of performance reference compounds (PRCs) during SPMD fabrication, differences in environmental exposure conditions between deployment sites, times and different monitoring programmes can be adjusted for by studying the dissipation of these compounds (Huckins et al., 2002; Booij et al., 1998). PRCs are non-native, non-interfering compounds characterised by moderate to high fugacities, usually added to the lipid of the SPMD during sampler construction, prior to field exposure. Information on the rate of PRC dissipation during field exposure of samplers can then be applied to estimate the in-situ sampling rates of the compounds of interest (Booij et al., 2010).

Although South Africa is a signatory of the Stockholm Convention and also has a relatively strong industrial presence, information on pollution by POPs remains scanty. Unlike the Northern Hemisphere countries which experience moderate climatic conditions and where most of the studies on POPs have been conducted, South Africa's climate is characterised by high temperatures, little precipitation and long summers (Quinn et al., 2009). Thus, findings from Northern Hemisphere studies cannot be reliably applied to the South African situation. Nevertheless, studies on POPs in South African, such as Nieuwoudt et al. (2011), Das et al. (2008), Bouwman (2003) and Bouwman et al. (1990), among others, have been documented in the literature, but are not adequate to fully describe the South African situation. Apart from a recent study by Degger et al. (2011) on the use of SPMDs to determine POPs in some South African marine environments, very little other information on application of passive sampling in South Africa is available in the literature.

This study was aimed at determining the water-dissolved concentrations of the 16 US EPA priority PAHs, PCBs and OCPs in Hartbeespoort Dam, South Africa, using SPMDs. Specifically, temporal trends in POP concentrations in the dam were investigated.

\section{MATERIALS AND METHODS}

\section{Chemicals and reagents}

The PAH standard mixture containing the 16 US EPA priority PAHs (all $>97 \%$ pure) was purchased from SigmaAldrich Chemie GmbH, Steinheim, Germany. Performance reference compounds $-\mathrm{D}_{10}$-acenaphthene, $\mathrm{D}_{10}$-fluorene, $\mathrm{D}_{10}$-phenanthrene and $\mathrm{D}_{10}$-pyrene - were sourced from Dr Ehrenstorfer GmbH, Augsburg, Germany. $\mathrm{D}_{8}$-Naphthalene, $\mathrm{D}_{10}$-anthracene, $\mathrm{D}_{12}$-fluoranthene, $\mathrm{D}_{12}$-benzo(a)anthracene, $\mathrm{D}_{12}$-benzo(k)fluoranthene, $\mathrm{D}_{12}$-benzo(g,h,i)pyrene, $\mathrm{PCB}$ 30, PCB 185 and $d_{6}$-gamma HCH (Dr Ehrenstorfer GmbH, Augsburg, Germany) were used as recovery standards. PCB 121 and terphenyl (Dr Ehrenstorfer GmbH, Augsburg, Germany) were used as internal standards for PCB and PAH instrumental analysis, respectively. Pesticide residue analysis grade $n$-hexane, dichloromethane, trichloromethane and all other solvents

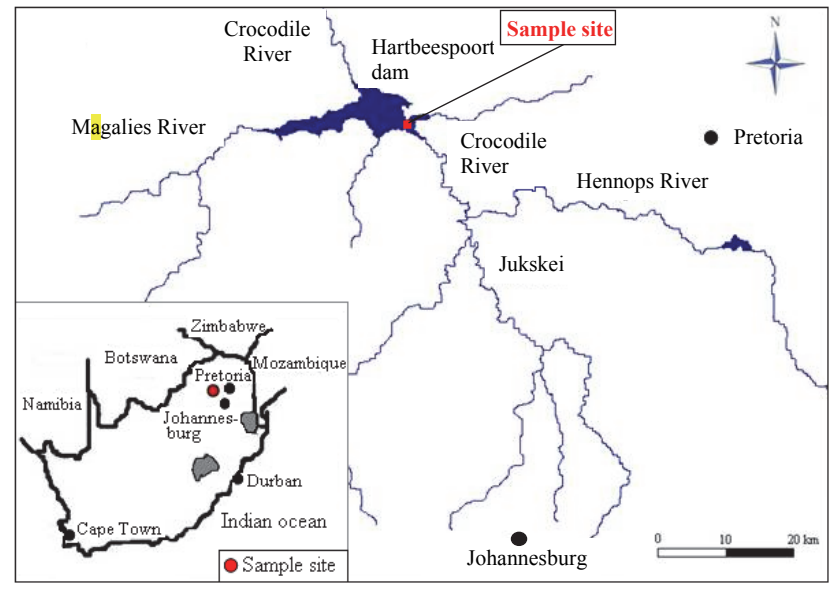

Figure 1

Map showing the sampling site in the Hartbeespoort Dam, South Africa

(all $>$ 97\% pure) used were purchased from Sigma-Aldrich (Prague, Czech Republic). Milli-Q water $(18 \mathrm{M} \Omega \cdot \mathrm{cm})$ was obtained from the Millipore Simplicity 185 system (Millipore, Bedford, MA, USA).

\section{Sampling site}

The sampling site was located in the Hartbeespoort Dam, $25^{\circ} 45^{\prime} 09.97^{\prime \prime} \mathrm{S}, 27^{\circ} 53^{\prime} 04.39^{\prime \prime} \mathrm{E}$, about $37 \mathrm{~km}$ west of Pretoria and on the Crocodile River in North West Province, South Africa (Fig. 1). The dam is a $20.7 \mathrm{~km}^{2}$ water reservoir sandwiched between the Magalies mountain range in the Highveld region of northern South Africa (Nyoni et al., 2011). The dam reservoir receives water from a catchment area of about $4100 \mathrm{~km}^{2}$, via the Jukskei and Hennops rivers that flow into the Crocodile River (Harding et al., 2004). The five catchment basins of the dam are, from west to east: the Magalies/Skeerpoort, the Crocodile, the Juskei, the Hennops and the Swartspruit basin (Van Rei, 1987). The Crocodile River accounts for about $90 \%$ of the dam's water supply with rainwater being the major source in summer. This scenario dramatically changes during the dry season (winter) as $50 \%$ of the water received by the dam then comprises treated wastewater from urbanised areas upstream (Harding et al., 2004), which creates environmental challenges for the water body. Although the origins of the Crocodile River system can be traced to the north of the city of Johannesburg, extensive rural crop farming is still carried out within the dam's drainage area, using its water. Considerable urban development is also present along the shorelines of the basin, and a portion of the impounded water from the dam is utilised for domestic supply, both within the riparian community and in downstream urban centres (DWA, 2012).

Monitoring of the water body for PAHs, PCBs and OCPs using SPMDs was done in each of the four seasons of the year: winter, spring, summer and autumn, as described in Table 1.

\section{Sampling procedure}

At the deployment site, the samplers, including the field controls, were unpacked from the metal cans and placed on clean aluminium foil. The samplers were then mounted onto the deployment devices (protected by a steel casing). Once ready, they were quickly immersed in the water at between 1 and $1.5 \mathrm{~m}$ depth below the water surface. The steel cages housing 
TABLE 1

Deployment periods and some water quality parameters

\begin{tabular}{|l|l|c|c|c|}
\hline & Sampling period & Water temperature $\left({ }^{\circ} \mathrm{C}\right)$ & $\mathrm{pH}$ & Dissolved oxygen $\left(\mathbf{m g} \cdot \ell^{-1}\right)$ \\
\hline Winter & $19-04-2011$ to $04-05-2011$ & 11.6 & 8.0 & 5.01 \\
\hline Spring & $19-08-2011$ to $02-09-2011$ & 14.2 & 8.2 & 5.23 \\
\hline Summer & 18-11-2011 to 02-12-2011 & 25.5 & 9.0 & 6.04 \\
\hline Autumn & 24-02-2012 to 09-03-2012 & 19.7 & 8.6 & 5.75 \\
\hline
\end{tabular}

the samplers were tied using ropes and anchored firmly to buoys. Finally, the field blanks were placed in airtight tin cans and transported in portable ice chests ('cool boxes') to the laboratory, where they were stored at $-20^{\circ} \mathrm{C}$.

\section{SPMD sampler preparation and deployment}

SPMDs (dimensions: $2.5 \times 91.4 \mathrm{~cm}, 460 \mathrm{~cm}^{2}$ external surface area, and a wall thickness of $70 \mu \mathrm{m}$ ) were prepared from LDPE layflat tubing (Brentwood Plastics, MO, USA) and filled with $1 \mathrm{~m} \ell$ of high purity triolein (1,2,3-tri(cis-9-octadecenoyl)glycerol) (99\% pure) which had previously been spiked with performance reference compounds, namely, fluorene- $\mathrm{d}_{10}$, acenaphthene- $d_{10}$, anthracene- $d_{10}$, phenanthrene- $d_{10}$ and pyrene- $d_{10}$, to yield a nominal concentration of $2 \mu \mathrm{g} \cdot \mathrm{g}^{-1}$ triolein. Prepared samplers were stored in airtight sealed metal cans under freezing temperatures $\left(-20^{\circ} \mathrm{C}\right)$ awaiting deployment. SPMDs were deployed in the water body in triplicates for a 14-day period. On retrieval, samplers were placed in airtight metal containers and quickly transported to the laboratory where they were stored at $-20^{\circ} \mathrm{C}$ until processing.

\section{SPMD processing}

After removing particulates and biofouling from the surface of affected SPMDs using a soft brush and tap water, they were briefly immersed in diluted (10\%) hydrochloric acid to rid them of adsorbed carbonates acquired during field deployment. The samplers were again flushed with sufficient amounts of tap water, and dried using acetone and a soft paper tissue. Each sampler was transferred into a pre-cleaned, empty $250 \mathrm{~m} \ell$ glass bottle with a ground joint stopper and $100 \mathrm{~m} \ell$ of HPLC grade n-hexane added. Each sampler was then spiked with surrogate standard solutions, namely, naphthalene- $\mathrm{d}_{8}$, fluoranthene- $\mathrm{d}_{12}$, benzo(a)anthracene- $d_{12}$, benzo(k)fluoranthene- $d_{12}$, benzo(g,h,i) pyrene- $\mathrm{d}_{12}$, PCB 30 and 85 , and $\mathrm{d}_{6}$-gamma $\mathrm{HCH}$, and extraction done twice for $24 \mathrm{~h}$ in the dark at room temperature. The extracts were combined and reduced to about $10 \mathrm{~m} \ell$ using a rotary evaporator (Heidolph Laborata4000, Germany) at $40^{\circ} \mathrm{C}$ before concentrating further to about $0.5 \mathrm{~m} \ell$. Finally, the extracts were reconstituted in $1 \mathrm{~m} \ell$ of pesticide residue analysis-grade trichloromethane.

Removal of lipids that diffused into the extract during dialysis was achieved using a gel permeation chromatography (GPC) system equipped with a high pressure pump (HPP5001) and a fraction collector (ECOM, Prague, Czech Republic). A gel $5 \mu \mathrm{m} 50 \AA$, 7.5 x $300 \mathrm{~mm}$, high performance size exclusion chromatography column (Agilent PL) was used to fractionate the extracts with chloroform as the mobile phase at a flow rate of $0.6 \mathrm{~m} \ell \cdot \mathrm{min}^{-1}$. Analytes were collected from $18 \mathrm{~min} 20 \mathrm{~s}$ to $41 \mathrm{~min} 40 \mathrm{~s}$ and reduced to the last drop using a gentle stream of nitrogen gas. Subsequently, the extract was reconstituted to $1 \mathrm{~m} \ell \mathrm{n}$-hexane. The GPC eluate was subjected to further cleanup by activated silica gel.
One portion (20\%) of the GPC extract targeting PAHs was cleaned using activated silica gel packed in a glass column and eluted with $10 \mathrm{~m} \ell$ of $n$-hexane followed by $20 \mathrm{~m} \ell$ of dichloromethane. The remaining portion (80\%) targeting PCBs and OCPs was cleaned with sulphuric acid-modified activated silica gel, prepared by mixing $33 \mathrm{~m} \ell$ of concentrated sulphuric acid (>98\%) with $50 \mathrm{~g}$ of freshly prepared activated silica gel. Thorough homogenisation of the mixture was ensured before column packing. Target analytes were eluted with $30 \mathrm{m \ell}$ dichloromethane. After reduction to $1 \mathrm{~m} \ell$ using a gentle stream of nitrogen gas, terphenyl or PCB 121 internal standards were added to the sample, and ultimately analysed by GC-MS/MS for PAHs and PCBs/OCPs, respectively.

\section{Instrumentation}

The PAHs of interest were analysed using a 6890 GC system coupled with a 5971 mass selective detector (Agilent Technologies). Chromatographic separation of the components was done using a capillary column $(30 \mathrm{~m}$ x $0.25 \mathrm{~mm}$ internal diameter, $0.25 \mu \mathrm{m}$ film thickness) HP-5MS and helium as the carrier gas flowing at $1.5 \mathrm{~m} \ell \cdot \mathrm{min}^{-1}$. Conditions of gas chromatography separation were as follows: injector temperature was set at $250^{\circ} \mathrm{C}$, initial column temperature was set at $70^{\circ} \mathrm{C}$ and held for $0.5 \mathrm{~min}$. This ramped at $25^{\circ} \mathrm{C} \cdot \mathrm{min}^{-1}$ to $150^{\circ} \mathrm{C}$. It was then ramped at $30^{\circ} \mathrm{C} \cdot \mathrm{min}^{-1}$ to $200^{\circ} \mathrm{C}$. This was further ramped at $8^{\circ} \mathrm{C} \cdot \mathrm{min}^{-1}$ to $280^{\circ} \mathrm{C}$ and held for $20 \mathrm{~min}$. Detection of the separated PAHs was achieved using a MS/MS system operated in selected ion monitoring mode with the electron impact ionisation set at $70 \mathrm{eV}$. The temperatures of the ion source, transfer line and the quadrupole were held at $230^{\circ} \mathrm{C}$, $280^{\circ} \mathrm{C}$ and $150^{\circ} \mathrm{C}$, respectively. Quantitation of the residues was accomplished using a 7-point standard calibration curve in the concentration range of 0 to $1000 \mathrm{ng} \cdot \ell^{-1}$. GC-MS/MS was used for indicator PCBs and OCPs analysis. 6890N GC (Agilent, USA) equipped with a $60 \mathrm{~m} \times 0.25 \mathrm{~mm} \times 0.25 \mu \mathrm{m}$ DB5-MS column (Agilent J\&W, USA) coupled to Quattro MicroGC MS (Waters, Micromass, UK) operated in EI+ was used; at least 2 MRM transitions were recorded for each compound analysed. Injection was done in splitless mode at $280^{\circ} \mathrm{C}$ and $1 \mu \ell$ sample loaded. Helium was used as carrier gas at the flow of $1.5 \mathrm{~m} \ell \cdot \mathrm{min}^{-1}$. The GC temperature programme was $80^{\circ} \mathrm{C}(1-\mathrm{min}$ hold), then $15^{\circ} \mathrm{C} \cdot \mathrm{min}^{-1}$ to $180^{\circ} \mathrm{C}$, and finally $5^{\circ} \mathrm{C} \cdot \mathrm{min}^{-1}$ to $300^{\circ} \mathrm{C}$ (5-min hold). Raw data were processed using TargetLynx software (Waters, Micromass, UK).

\section{Quality control}

Fabrication controls and field blanks were used to account for contamination of the SPMDs during device construction, and sampler deployment and retrieval from the site. Vapour-phase contamination during deployment of the SPMDs was factored in by the field blanks. These blanks were subjected to identical processing treatment as the deployed devices. 


\begin{tabular}{|c|c|c|c|c|}
\hline \multicolumn{5}{|c|}{$\begin{array}{c}\text { TABLE } 2 \\
\text { Mean concentrations of PAHs, OCPs and DDTs in SPMDs ( } \mathrm{ng} \mathrm{SPMD}{ }^{-1}, \mathrm{n}=3 \text { ) }\end{array}$} \\
\hline \multirow[t]{2}{*}{ Compound } & \multicolumn{4}{|c|}{ Season } \\
\hline & Winter & Spring & Summer & Autumn \\
\hline \multicolumn{5}{|l|}{ PAHs } \\
\hline Naphthalene & $307 \pm 11$ & $149 \pm 11$ & $171 \pm 4$ & $286 \pm 20$ \\
\hline Acenaphthylene & $158 \pm 5$ & $76 \pm 6$ & $132 \pm 2$ & $180 \pm 7$ \\
\hline Acenaphthene & $37 \pm 3$ & $20 \pm 2$ & $25 \pm 1$ & $38 \pm 3$ \\
\hline Fluorene & $76 \pm 11$ & $61 \pm 7$ & $49 \pm 4$ & $106 \pm 7$ \\
\hline Phenanthrene & $164 \pm 36$ & $71 \pm 9$ & $75 \pm 5$ & $217 \pm 13$ \\
\hline Anthracene & $875 \pm 40$ & $279 \pm 5$ & $56 \pm 12$ & $164 \pm 3$ \\
\hline Fluoranthene & $147 \pm 4$ & $65 \pm 3$ & $119 \pm 11$ & $97 \pm 7$ \\
\hline Pyrene & $105 \pm 2$ & $49 \pm 3$ & $88 \pm 5$ & $83 \pm 8$ \\
\hline Benz[a]anthracene & $31 \pm 1$ & $16 \pm 1$ & $32 \pm 2$ & $33 \pm 1$ \\
\hline Chrysene & $41 \pm 1$ & $22 \pm 5$ & $45 \pm 6$ & $44 \pm 1$ \\
\hline Benzo[b]fluoranthene & $35 \pm 4$ & $26 \pm 8$ & $36 \pm 1$ & $38 \pm 2$ \\
\hline Benzo[k]fluoranthene & $36 \pm 2$ & $\mathrm{ND}$ & $36 \pm 2$ & $38 \pm 2$ \\
\hline Benzo[a]pyrene & $34 \pm 6$ & $32 \pm 0$ & $39 \pm 7$ & $43 \pm 5$ \\
\hline Indeno[1,2,3-cd]pyrene & $37 \pm 0$ & $19 \pm 1$ & $38 \pm 1$ & $39 \pm 1$ \\
\hline Dibenz[a,h]anthracene & ND & ND & $\mathrm{ND}$ & ND \\
\hline Benzo[ghi]perylene & $35 \pm 1$ & $20 \pm 2$ & $41 \pm 3$ & $45 \pm 2$ \\
\hline इPAHs & $2117 \pm 57$ & $905 \pm 21$ & $984 \pm 21$ & $1450 \pm 29$ \\
\hline \multicolumn{5}{|l|}{ HCHs } \\
\hline HCB 28 & $1.1 \pm 0.2$ & $0.9 \pm 0.1$ & $0.7 \pm 0.0$ & $0.6 \pm 0.1$ \\
\hline$a-\mathrm{HCH}$ & $55.9 \pm 3.5$ & $52.5 \pm 5.1$ & $32.3 \pm 3.6$ & $64.8 \pm 5.5$ \\
\hline$\beta-\mathrm{HCH}$ & $154.3 \pm 7.8$ & $153.4 \pm 0.4$ & $70.9 \pm 4.0$ & $45.5 \pm 2.9$ \\
\hline Lindane & $8.8 \pm 0.9$ & $8.1 \pm 0.1$ & $5.9 \pm 0.8$ & $9.8 \pm 0.9$ \\
\hline$\delta-\mathrm{HCH}$ & $3.2 \pm 0.2$ & $3.1 \pm 0.2$ & $1.4 \pm 0.2$ & $2.5 \pm 0.4$ \\
\hline e-HCH & $9.9 \pm 0.6$ & $9.8 \pm 0.6$ & $4.5 \pm 0.1$ & $5.6 \pm 0.7$ \\
\hline$\Sigma \mathrm{HCHs}$ & $233.2 \pm 8.6$ & $227.7 \pm 5.2$ & $106.5 \pm 5.4$ & $128.7 \pm 6.3$ \\
\hline \multicolumn{5}{|l|}{ DDTs } \\
\hline$o, p^{\prime}-D D E$ & $0.6 \pm 0.1$ & $0.8 \pm 0.1$ & $0.4 \pm 0.0$ & $0.3 \pm 0.0$ \\
\hline p,p'-DDE & $5.3 \pm 0.2$ & $5.5 \pm 0.4$ & $3.6 \pm 0.3$ & $3.1 \pm 0.2$ \\
\hline$o, p^{\prime}-D D D$ & $10.8 \pm 1.1$ & $13.6 \pm 0.2$ & $5.0 \pm 0.4$ & $4.2 \pm 0.4$ \\
\hline p,p'-DDD & $31.1 \pm 0.6$ & $43.5 \pm 0.8$ & $15.7 \pm 3.1$ & $19.9 \pm 2.7$ \\
\hline o,p'-DDT & ND & $\mathrm{ND}$ & $\mathrm{ND}$ & ND \\
\hline p,p'DDT & $0.6 \pm 0.1$ & $0.7 \pm 0.1$ & $0.7 \pm 0.1$ & $0.7 \pm 0.1$ \\
\hline$\Sigma$ DDTs & $48.5 \pm 1.3$ & $64.1 \pm 0.9$ & $25.3 \pm 3.1$ & $28.2 \pm 2.7$ \\
\hline \multicolumn{5}{|l|}{ PCBs } \\
\hline PCB 28 & $3.5 \pm 0.50$ & $3.1 \pm 0.30$ & $1.5 \pm 0.10$ & $2.1 \pm 0.17$ \\
\hline PCB 52 & $1.1 \pm 0.06$ & $1.0 \pm 0.09$ & $0.6 \pm 0.00$ & $0.5 \pm 0.04$ \\
\hline PCB 101 & $0.4 \pm 0.06$ & $0.4 \pm 0.03$ & $0.3 \pm 0.07$ & $0.4 \pm 0.01$ \\
\hline PCB 118 & $0.2 \pm 0.02$ & $0.2 \pm 0.00$ & $0.2 \pm 0.01$ & $0.2 \pm 0.00$ \\
\hline PCB 153 & $0.5 \pm 0.03$ & $0.5 \pm 0.07$ & $0.4 \pm 0.02$ & $0.7 \pm 0.05$ \\
\hline PCB 138 & $0.6 \pm 0.05$ & $0.3 \pm 0.00$ & $0.5 \pm 0.05$ & $0.5 \pm 0.05$ \\
\hline PCB 180 & $0.3 \pm 0.02$ & $0.3 \pm 0.00$ & $0.5 \pm 0.02$ & $0.4 \pm 0.02$ \\
\hline$\Sigma$ PCBs & $6.5 \pm 0.51$ & $5.8 \pm 0.32$ & $3.9 \pm 0.14$ & $4.8 \pm 0.19$ \\
\hline
\end{tabular}

ND: not detected

\section{RESULTS AND DISCUSSION}

\section{Occurrence of PAHs, PCBs and OCPs in the SPMDs}

The absolute contaminant concentrations sequestered by SPMDs deployed at Hartbeespoort Dam during the 14-day deployment period in each of the four seasons of the year are presented in Table 2. Characteristic ions ( $\mathrm{m} / \mathrm{z}$ values) used in the analysis of polycyclic aromatic hydrocarbons in single ion monitoring (SIM) mode by GC/MS and characteristic MRM transitions ( $\mathrm{m} / \mathrm{z}$ values of parent and daughter ions) used in the analysis of PCBs and OCPs are given in the Appendix (Tables A1 and A2). Analyte concentrations were adjusted with respect to their recoveries obtained from recovery standards introduced prior to the dialytic process. The SPMD field blanks showed no quantifiable concentrations of the target 
contaminants. Determination of recoveries for all samples was carried out by spiking them with surrogate standards prior to extraction. Good recoveries were recorded that ranged from $55 \%$ to $123 \%$ for PAHs, $73 \%$ to $94 \%$ for PCBs and $72 \%$ to $104 \%$ for OCPs. The relative standard deviations between codeployed triplicate samplers did not exceed 22\% for PAHs, $24 \%$ for PCBs and $17 \%$ for OCPs. Limits of detection (LOD) and quantification (LOQs) for the method were 0.1 and $0.4 \mathrm{ng} \cdot \ell^{-1}$, respectively for PAHs. LODs for PCBs and OCPs were all less than $0.1 \mathrm{ng} \cdot \ell^{-1}$ whereas LOQs were $0.1 \mathrm{ng} \cdot \ell^{-1}$.

\section{Estimation of dissolved water concentrations of analytes}

Dissolved water concentrations of target analytes were calculated from amounts accumulated in SPMDs as follows: Amounts of analytes absorbed by the samplers follow a firstorder approach to equilibrium. Aqueous concentrations were calculated from the amounts $\left(N_{s}\right)$ absorbed by the SPMD, the in-situ sampling rate of the compounds $R_{s}$ and their samplerwater partition coefficients $K_{s w}$ :

$$
C_{\mathrm{w}}=\frac{N_{\mathrm{s}}}{K_{\mathrm{sw}} V_{\mathrm{s}}\left[1-\exp \left(-R_{\mathrm{s}} t /\left(K_{\mathrm{sw}} V_{\mathrm{s}}\right)\right)\right]}
$$

where:

$V_{\mathrm{S}}$ is the volume of the SPMD and $t$ is the sampler exposure time.

PRC dissipation also follows first-order kinetics. Sampling rates $R_{\mathrm{s}}$ were estimated using the non-linear least -squares method of Booij and Smedes (2010), considering the fraction $f$ of individual PRCs $\left(\mathrm{D}_{10}\right.$-acenaphthene, $\mathrm{D}_{10}$-fluorene, $\mathrm{D}_{10}$-phenanthrene and $\mathrm{D}_{10}$-pyrene) that remained in the SPMD after the 14-day exposure as a continuous function of their $K_{\mathrm{sw}}$, with $R_{\mathrm{S}}$ as an adjustable parameter.

$$
f=\exp \left(-\frac{R_{S} t}{K_{S W} V_{S}}\right)
$$

where:

$f=N_{\text {PRC }} / N_{0, \mathrm{PRC}} ; N_{0, \mathrm{PRC}}$ is the initial amount of the PRC at $t=0$ $N_{\text {PRC }}$ is amount of each PRC remaining after exposure $t$ is exposure period (14 days).

Assuming water boundary layer controlled uptake, $R_{\mathrm{s}}$ of individual target compounds in the higher hydrophobicity range was estimated by substituting Eq. (3), derived by Rusina et al. (2010), into Eq. (2).

$$
R_{S}=F A M^{-0.47}
$$

where: $M$ is the molecular weight of the analyte, $A$ is the surface area of SPMD $\left(460 \mathrm{~cm}^{2}\right)$ and $F$ is the regression coefficient that was optimised using the non-linear least squares method for estimating sampling rates. The necessary $K_{\mathrm{sw}}$ values were interpolated from the empirical equation (Huckins et al., 2006).

$$
\log K_{\mathrm{sw}}=-01618\left(\log K_{\mathrm{ow}}\right)^{2}+2.321 \log K_{\mathrm{ow}}-2.61
$$

The calculated free dissolved water concentrations of the PAHs, PCBs and OCPs are presented in Table 3.

\section{Temporal trends of water-dissolved contaminants}

Equation (3), which estimates a slight decrease in $R_{\mathrm{s}}$ with increasing molecular mass, was used to calculate compoundspecific $R_{\mathrm{s}}$ values for all of the compounds studied. Depending on the water flow velocities, different $R_{\mathrm{s}}$ values were obtained in the various seasons, in agreement with the assumption of water boundary layer uptake. Mass transfer of analytes may also be affected by other factors such as temperature, biofouling and deposition of particulates on the surface of the SPMDs.

Estimated water soluble concentrations generally followed the trend: PAHs $>$ OCPs $>$ PCBs. PAHs are ubiquitous organic pollutants characterised by many natural and anthropogenic sources, unlike OCPs and PCBs (industrial products). Since the dam receives over $90 \%$ of its water from the Crocodile River, which originates in Johannesburg city, it is possible that a good portion of the pollutants sampled could be of industrial origin. $\mathrm{PCB}$ concentrations are on average 2 to 3 orders of magnitude lower than those of PAHs and OCPs because most of these manufactured products have long been banned and their use stopped, in line with the Stockholm Convention, and whatever was captured by the samplers is attributable to their environmental persistence due to slow degradation. The sum total of water-borne concentrations of the compounds ranged from 30.2 to $60.8 \mathrm{ng} \cdot \ell^{-1}$ (PAHs), 10.0 to $10.7 \mathrm{ng} \cdot \ell^{-1}$ (OCPs) and 38 to $150 \mathrm{pg} \cdot \ell^{-1}$ (PCBs). Generally, the seasonal trends for all of the compounds mirrored the amounts accumulated in the SPMDs. An observed predominance of smaller molecular weight PAHs was evident in all four seasons. This may be attributed to their higher solubility in water due to lower hydrophobicity and, hence, transportation from the point sources was probably more efficient.

\section{PAHs}

A remarkable seasonal variability in the amounts of sequestered PAHs was shown by the deployed SPMDs. Estimated total analyte concentrations ranged from $30.0 \mathrm{ng} \cdot \ell^{-1}$ (in summer) to a high of $60.8 \mathrm{ng} \cdot \ell^{-1}$ (in winter). These concentrations are comparable to those reported by Wang et al. (2009) (13.8$\left.97.2 \mathrm{ng} \cdot \ell^{-1}\right)$ at the Three Gorges River, China, and Vrana et al. (2014) (5-72 ng. $\left.\ell^{-1}\right)$ in the Danube River, Slovakia/Austria. The trend of total concentrations of PAHs dissolved in water was as follows: winter $>$ spring $>$ autumn $>$ summer. Individual PAH concentrations obtained in the various seasons also generally followed the same trend as the totals (Fig. 2). Smaller molecular weight PAHs constituted the highest percentage of the sequestered compounds.

The reported water-soluble concentrations of the heavy molecular weight PAHs in the current study were on average up to 2 orders of magnitude lower than the maximum contaminant limits (MCL) set by international regulatory bodies such as the United States Environmental Protection Agency (USEPA) (0.01 to $\left.0.04 \mu \mathrm{g} \cdot \ell^{-1}\right)$.

The elevated concentrations recorded during winter may be attributed to a number of factors. During the winter months, very little precipitation is recorded (average of about 4-9 $\mathrm{mm}$ for the study area) and, since the dam depends on river water for replenishment, its volume drastically drops. This in turn increases the percentage of the dam's water originating from treated wastewater, which can exceed $50 \%$ of the total volume (Harding et al., 2004). These wastewater treatment plants are located in the industrialised areas north of Johannesburg. In addition, average temperatures substantially drop during winter (to an average air temperature of $4-7^{\circ} \mathrm{C}$ as measured in the study area) which in turn discourages analyte losses via volatilisation. Atmospheric deposition of PAHs represents an 


\begin{tabular}{|c|c|c|c|c|}
\hline \multicolumn{5}{|c|}{$\begin{array}{l}\text { TABLE } 3 \\
\text { Estimated dissolved water concentrations, } C_{w^{\prime}}\left(\mathrm{ng} \cdot \ell^{-1}\right) \text { of PAHs, PCBs and OCPs from SPMDs deployed at } \\
\text { Hartbeespoort Dam in different seasons of the year }\end{array}$} \\
\hline \multirow[b]{2}{*}{ Compound } & \multicolumn{4}{|c|}{ Season } \\
\hline & Winter & Spring & Summer & Autumn \\
\hline \multicolumn{5}{|l|}{ PAHs } \\
\hline Naphthalene & 43.153 & 43.206 & 23.980 & 38.499 \\
\hline Acenaphthylene & 3.862 & 3.897 & 3.214 & 4.354 \\
\hline Acenaphthene & 1.115 & 1.173 & 0.759 & 1.099 \\
\hline Fluorene & 1.176 & 1.858 & 0.716 & 1.646 \\
\hline Phenanthrene & 1.283 & 1.316 & 0.386 & 1.808 \\
\hline Anthracene & 7.321 & 2.200 & 0.310 & 1.519 \\
\hline Fluoranthene & 0.709 & 1.340 & 0.223 & 0.639 \\
\hline Pyrene & 0.698 & 0.994 & 0.170 & 0.561 \\
\hline Benz[a]anthracene & 0.169 & 0.287 & 0.051 & 0.231 \\
\hline Chrysene & 0.226 & 0.422 & 0.072 & 0.302 \\
\hline Benzo[b]fluoranthene & 0.221 & 0.511 & 0.060 & 0.279 \\
\hline Benzo[k]fluoranthene & 0.222 & ND & 0.060 & 0.282 \\
\hline Benzo[a]pyrene & 0.199 & 0.294 & 0.065 & 0.233 \\
\hline Indeno[1,2,3-cd]pyrene & 0.221 & 0.362 & 0.063 & 0.297 \\
\hline Dibenz[a,h]anthracene & ND & ND & ND & ND \\
\hline Benzo[ghi]perylene & 0.211 & 0.365 & 0.070 & 0.343 \\
\hline$\Sigma \mathrm{PAHs}$ & 60.768 & 58.225 & 30.199 & 52.082 \\
\hline \multicolumn{5}{|l|}{ HCHs } \\
\hline$\alpha-\mathrm{HCH}$ & 2.320 & 2.212 & 0.666 & 2.921 \\
\hline$\beta-\mathrm{HCH}$ & 6.780 & 6.661 & 8.102 & 6.151 \\
\hline Lindane & 0.445 & 0.389 & 0.189 & 0.542 \\
\hline$\delta-\mathrm{HCH}$ & 0.054 & 0.062 & 0.024 & 0.087 \\
\hline$\varepsilon-\mathrm{HCH}$ & 0.442 & 0.386 & 0.187 & 0.260 \\
\hline$\Sigma \mathrm{HCHs}$ & 10.350 & 10.201 & 9.168 & 9.961 \\
\hline \multicolumn{5}{|l|}{ DDTs } \\
\hline$o, p^{\prime}-D D E$ & 0.004 & 0.006 & 0.010 & 0.007 \\
\hline p,p-DDE & 0.033 & 0.052 & 0.088 & 0.062 \\
\hline$o, p^{\prime}-D D D$ & 0.065 & 0.104 & 0.176 & 0.124 \\
\hline p,p'-DDD & 0.203 & 0.323 & 0.547 & 0.384 \\
\hline p,p'-DDT & ND & ND & ND & $\mathrm{ND}$ \\
\hline p,p'-DDT & 0.004 & 0.006 & 0.011 & 0.008 \\
\hline$\Sigma$ DDTs & 0.309 & 0.491 & 0.832 & 0.585 \\
\hline \multicolumn{5}{|l|}{ PCBs } \\
\hline PCB 28 & 0.019 & 0.029 & 0.067 & 0.020 \\
\hline PCB 52 & 0.006 & 0.012 & 0.025 & 0.010 \\
\hline PCB101 & 0.003 & 0.005 & 0.014 & 0.007 \\
\hline PCB 118 & 0.001 & 0.001 & 0.003 & ND \\
\hline PCB 138 & 0.003 & 0.006 & 0.013 & 0.005 \\
\hline PCB 153 & 0.004 & 0.005 & 0.018 & 0.004 \\
\hline PCB 180 & 0.002 & 0.004 & 0.012 & 0.003 \\
\hline$\Sigma$ PCBs & 0.038 & 0.062 & 0.150 & 0.049 \\
\hline
\end{tabular}

ND: not detected

important pathway for PAHs into the aquatic ecosystem. The increased concentrations in water in winter may correspond with elevated atmospheric concentrations during the same period due to enhanced combustion of coal for heating. The summer months experience high rainfall coupled with high temperatures. Resuspension of sediment-immobilised PAHs was expected to increase PAH concentrations in the water phase. Inputs from runoff and rivers originating from polluted areas upstream were also thought to be potential PAH sources.
Although these factors may have been at play, it seems dilution effects (larger water volumes) as well as losses through volatilisation may have tempered the expected increase in contaminant concentrations. The autumn season is characterised by less precipitation and dropping temperatures. These conditions may have led to lower contaminant losses via volatilisation coupled with increased concentration due to decreased bulk water volumes.

The PCB concentrations obtained from the deployed 

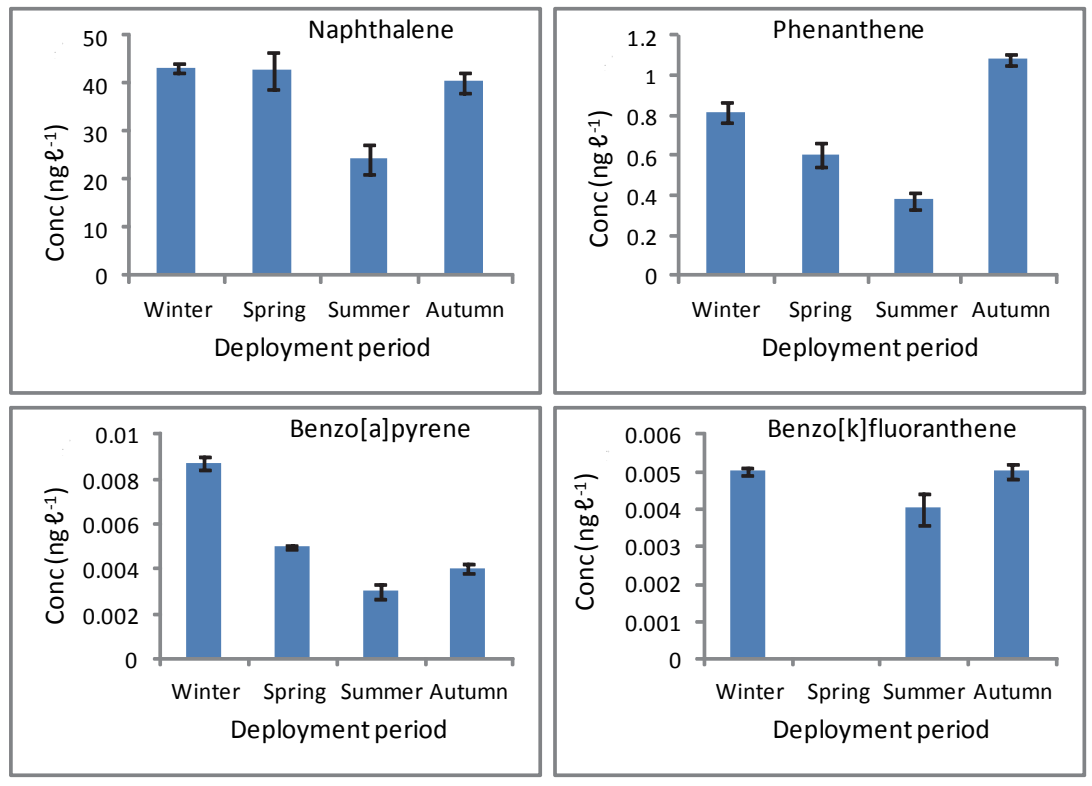

Figure 2

Temporal changes

in water-dissolved

concentrations of some

individual PAHs at the site
SPMDs were generally lower, by about 2 to 3 orders of magnitude, than PAH and OCP concentrations. PCBs are organic contaminants of purely anthropogenic origin, in contrast to PAHs that have both natural and anthropogenic sources. In addition, most PCBs were banned some years back and the remnants captured by the samplers are as a result of the strong persistence of PCBs in the environment. Due to their strong hydrophobicity (shown by higher $\log K_{\text {ow }}$ values of up to several orders of magnitude), PCBs tend to partition away from the water phase and preferentially adsorb strongly onto particulate matter, colloids and sediments in water. Moreover, their emissions are likely to be much lower than those of PAHs because, unlike the western industrialised countries, South Africa may not have utilised PCBs heavily during its economic growth in the 1980s or later when usage of PCBs was banned (Ogata et al., 2009).

Estimated water concentrations of the sum total of PCBs are shown in Table 3. When ranked in increasing order, the water-dissolved analyte concentrations followed the trend: summer $>$ spring $>$ autumn $>$ winter. Concentrations of the compounds ranged from a low of $0.038 \mathrm{ng} \cdot \ell^{-1}$ in winter to a high of $0.150 \mathrm{ng} \cdot \ell^{-1}$ in summer. These concentrations were comparable to those obtained by Vrana et al. (2014) in the Danube River (5 to $16 \mathrm{pg} \cdot \ell^{-1}$ ) and Allan and Ranneklev (2011) in the Alna River, Norway ( 0.7 to $\left.85 \mathrm{pg} \cdot \ell^{-1}\right)$. Clearly, PCB levels in summer were significantly higher than those recorded in all of the other seasons. This observation may be explained as follows: In the summer rainfall region of South Africa, within which the study area lies, the summer period usually experiences heavy rainfall (90-125 mm)

Most PCB congeners are highly hydrophobic compounds which preferentially adsorb strongly onto soil particles and sediments. Therefore, heavy rain events may disrupt these strong interactions thereby remobilising them into the water phase. This is partly supported by the fact that usage of these compounds has been banned for several years and therefore a majority of inputs could be coming from sediment samples. Surface runoff from urban centres (where these compounds are found in higher quantities) may also add to the pollutant load. A good portion of the water that eventually finds its way to the sample site can be traced to the industrial areas of Johannesburg (Fig. 1).
The estimated freely dissolved water concentrations of OCPs are given in Table 3. Seasonal ranking from lowest to highest followed the trend: summer, autumn, spring, winter. The sequestered amounts of OCPs that comprised hexachlorocyclohexanes (HCHs), and DDX (DDTs, DDDs and DDEs) were up to 2 orders of magnitude higher than PCBs but slightly less than those of PAHs. Among the analysed OCPs, HCHs contributed over $78 \%$ of the quantified amount and their free dissolved concentrations ranged from about $9.2 \mathrm{ng} \cdot \ell^{-1}$ in summer to 10.4 $\mathrm{ng} \cdot \ell^{-1}$ in winter. Figure 3 presents the water dissolved concentrations of selected $\mathrm{HCH}$ isomers.

Particularly high levels of $\beta-\mathrm{HCH}$ were detected at the sampling site in all four seasons. This HCH isomer is characterised by a much lower vapour pressure, better solubility in water, and lower Henry's law constant than all of the other $\mathrm{HCH}$ isomers, which favour partitioning from air to water. Compared to the gamma- and alpha-HCHs, it is the most recalcitrant isomer (Stockholm Convention, 2007).

In a global monitoring study of persistent organic pollutants (POPs) in coastal waters, Ogata et al. (2009) reported high concentrations of $\mathrm{HCHs}$ in samples from South Africa. This was in contrast to levels obtained in other parts of the world (such as USA, Asia and Europe) which were lower. They attributed this observation to the application of lindane in South Africa, which contains $\gamma-\mathrm{HCH}$ as its main component. It is possible that technical-grade $\mathrm{HCH}$ that also contain considerable amounts of $\beta-\mathrm{HCH}(5-12 \%)$ were applied. Because of its relative volatility, this globally-banned pesticide can easily find its way into water systems via atmospheric deposition.

In the soil-air interface, ratios of $\mathrm{HCH}$ isomers have been used to identify the historical pollution sources (Willett et al., 1998). $\beta-/(\alpha+\gamma)-\mathrm{HCH}>0.5$ is an indicator of historical pollution while a ratio less than 0.5 indicates new introduction of HCHs. In the case of the current study, these ratios ranged from 1.8 in autumn to a high of 9.5 in summer. It is therefore proposed that in all four seasons, $\mathrm{HCH}$ input to the sampling site is predominantly historical in nature with minimal inputs from current application.

Since the overall seasonal trends of $\mathrm{HCHs}$ generally mirrored those of PAHs (with the exception of values obtained in spring), we conclude that the same factors may have affected 

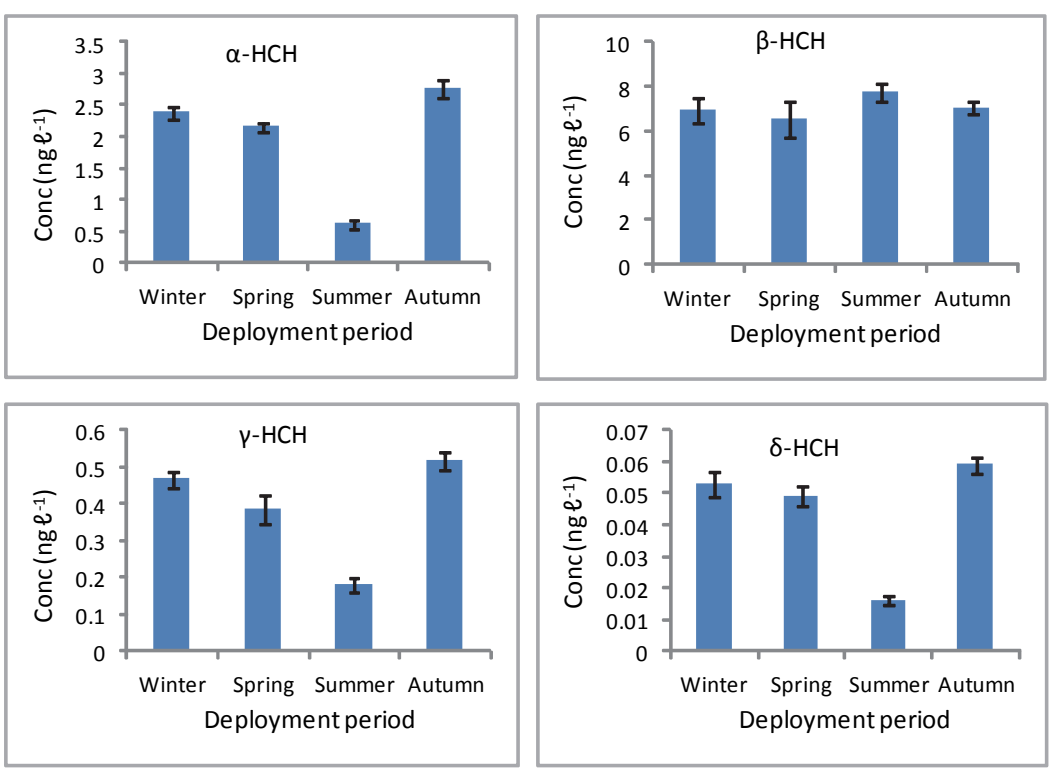

Figure 3

Water dissolved

concentrations of individual $\mathrm{HCHs}$ as affected by seasonal change them. However, the decrease in OCP concentrations from winter to spring was insignificant. This observation may be attributed to their comparatively lower volatility. Thus, losses through volatilisation resulting from increased temperatures during spring may not have been a major factor.

Interestingly, DDT and its metabolite residues showed seasonal patterns similar to those of PCBs, even though their water dissolved concentrations were generally higher. Estimated water concentrations of the DDT sum ranged from $0.31 \mathrm{ng} \cdot \ell^{-1}$ in winter to $0.83 \mathrm{ng} \cdot \ell^{-1}$ in summer, respectively. Volatilisation is a major route through which DDT and its metabolites are released into the atmosphere and, once there, these chemicals are cycled back to surface water through dry and wet deposition (Stockholm Convention, 2007). Findings from this study suggest that wet deposition of DDT and its metabolites may be playing an important role in re-introducing them to the sample site, as higher water concentrations coincide with high precipitation (summer). Moreover, considering the relatively high log $K_{\text {ow }}$ values associated with DDX (5.8-6.79), remobilisation of the particle/sediment-bound fraction as a consequence of heavy rainfall may have been a possibility. Contributions from runoff originating from fields also cannot be ignored. Taken together, these factors may explain the seasonal trends of DDX.

\section{Source identification of PAHs in the Hartbeespoort Dam}

The principal sources of PAHs in the environment can be classified as either pyrogenic or petrogenic, with the pyrogenic inputs predominating in aquatic environments (Ekpo et al., 2012). Based on the SPMD-obtained PAH concentrations, identification of the probable sources was attempted. Reports by many authors on the apportionment of PAH sources in the environment using molecular ratios of certain PAHs are available in the literature (Baumard et al., 1998; Vrana et al., 2001; Zhang et al., 2004; Brandli et al., 2008). With respect to passive sampling, ratios of PAHs must be for compounds with near identical sampling rates to minimise bias arising from the mode of calculation of the rates for compounds with widely differing $\log K_{\mathrm{ow}}$ (Allan and Raneklev, 2011). Furthermore, the same authors observed that unless PAHs are directly emitted to surface water, dissolved phase concentrations may not necessarily be representative of sources of contamination. From among the several available approaches, ratios of fluoranthene/ (fluoranthene + pyrene) $[\mathrm{Flt} /(\mathrm{Flt}+\mathrm{Pyr})]$ and anthracene/ (anthracene + phenanthrene) $[$ Ant/(Ant + Phe) $]$ calculated from waterborne concentrations were applied in the identification of the possible sources of PAHs in the site.

Figure 4 shows the diagnostic ratios of PAH concentrations measured with SPMDs in Hartbeespoort Dam. An Flt/ $($ Flt + Pyr $)$ ratio $>0.5$ indicates a pyrogenic source, as does an Ant/(Ant + Phe) ratio $>0.5$. Ratios of indeno[1,2,3-cd $]$ pyrene/(indeno[1,2,3-cd]pyrene + benzo[g,h,i]perylene) greater than 0.5 point to fossil fuel combustion or pyrogenic sources (Brandli et al., 2008) for the PAHs in the Hartbeespoort Dam. Thus, with the exception of concentrations obtained from SPMDs deployed in winter, all PAHs pointed to a pyrogenic origin. The winter-derived data showed a mixture of both pyrogenic and petroleum combustion sources. The spike in the petrogenic PAH fraction during winter may be attributed to the increased proportion of treated wastewater originating from Johannesburg. As Harding et al. (2004) reported, during winter, precipitation is almost nil and, consequently, more than $50 \%$ of the reservoir's inlet water is composed of treated wastewater. A steep increase in the Flt/(Flt + Pyr) ratio was observed from winter to spring before decreasing during summer. A further drop in the ratio, albeit gently, occurred between summer and autumn.

\section{CONCLUSIONS}

SPMDs are potentially effective tools for monitoring hydrophobic contaminants in aqueous systems such as those present in the Hartbeespoort Dam, South Africa. In addition to detecting concentrations of PAHs, PCBs and OCPs in the toxicologically most relevant dissolved phase, SPMDs also captured their seasonal variation in the water body. Generally, total contaminant concentrations in the dam increased in the order: summer, spring, autumn, winter. Concentrations of the $\mathrm{PAH}$ and $\mathrm{HCH}$ isomers decreased with increasing water temperature, which likely reflects seasonality of atmospheric deposition. The dissolved concentrations of PCB and DDT isomers are most likely related to desorption from suspended particles. Diagnostic ratios of PAHs measured in SPMDs were used to identify the possible sources of PAHs in the water. These ratios indicated 


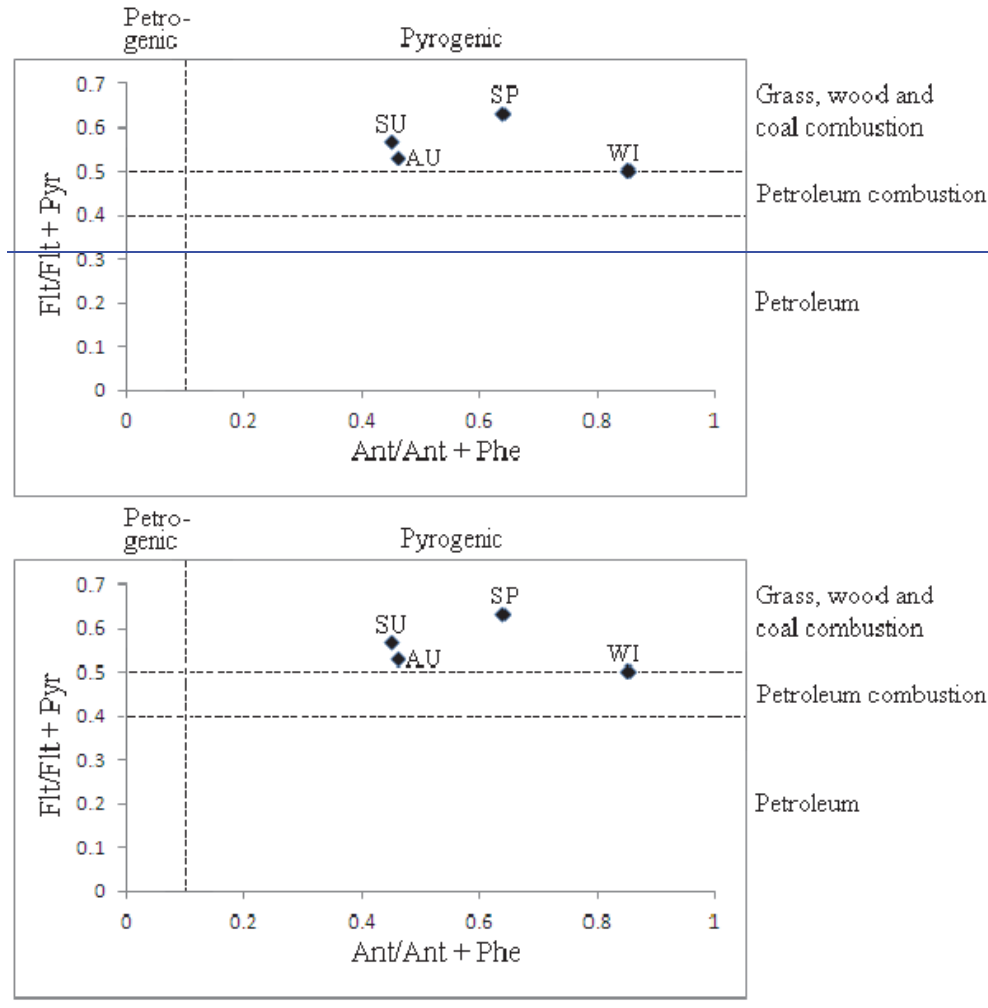

Figure 4

Diagnostic ratios of PAH concentrations measured with SPMDs in the Hartbeespoort Dam. WI: winter; SP: spring, SU: summer, AU: autumn, Flt: fluoranthene, Pyr: pyrene, Ant: anthracene, Phe: phenanthrene. that the PAH concentrations in the dam during spring, summer and autumn were mainly of pyrogenic origin while the winter levels comprised both pyrogenic and petrogenic sources.

\section{ACKNOWLEDGEMENTS}

The authors would like to thank Lenka Vaňková of RECETOX, Masaryk University, Czech Republic, for technical assistance and for financial support from the European Regional Development Fund, from the Ministry of Education of the Czech Republic (LM2011028 and LO1214), the project "Employment of Best Young Scientists for International Cooperation Empowerment" (CZ.1.07/2.3.00/30.0037) cofinanced from European Social Fund and the state budget of the Czech Republic, as well as from the National Research Foundation and Water Research Commission of South Africa.

\section{REFERENCES}

ALLAN IJ and RANNEKLEV SB (2011) Occurrence of PAHs and PCBs in the Alna River, Oslo (Norway). J. Environ. Monit. 13 2420-2426.

ATSDR (AGENCY FOR TOXIC SUBSTANCES AND DISEASE REGISTRY) (2009) Toxicological profile for polycyclic aromatic hydrocarbons (PAHs). Case studies in environmental medicine. United States Department of Health Services, Public Health Service, Atlanta, Georgia, U.S.A.

BAUMARD P, BUDZINSKI H, GARRIGUES Q, BURGEOT T and BELLOCQ J (1998) Origin and bioavailability of PAHs in the Mediterranean Sea from mussel and sediment records. Estuar. Coast. Shelf Sci. 47 77-90.

BOOIJ K and SMEDES F (2010) An improved method for estimating in situ sampling rates of nonpolar passive samplers. Environ. Sci. Technol. 44 6789-6794.

BOOIJ K, SLEIDERINK HM and SMEDES F (1998) Calibrating the uptake kinetics of semipermeable membrane devices using exposure standards. Environ. Toxicol. Chem. 17 1236-1245.
BOOIJ K, VRANA B and HUCKINS JN (2007) Theory, modelling and calibration of passive samplers used in water monitoring. In: Greenwood R, Mills G and Vrana B (ed.) Passive Sampling Techniques in Environmental Monitoring: Comprehensive Analytical Chemistry Series Vol. 48. Elsevier, Amsterdam. 141-169. BOUWMAN H (2003) POPs in South Africa: The handbook of environmental chemistry. Persistent Org. Pollut. 3 (0) 297-320.

BOUWMAN H, COOPAN RM, REINECKE AJ and BECKER PJ (1990) Levels of DDT and metabolites in breast milk from KwaZulu mothers after DDT application for malaria control. Bull. World Health Organ. 68 761-768.

BRANDLI RC, BUCHELI TD, AMMANN S, DESAULES A, KELLER A, BLUM F and STAHEL WA (2008) Lipid containing semipermeable membrane devices for monitoring organic contaminants in water. J. Environ. Monit. 10 1278-1286.

DAS SK, ROUTH J and ROYCHOUDHURY A (2008) Sources and historic changes in polycyclic aromatic hydrocarbon input in a shallow lake, Zeekoevlei, South Africa. Org. Geochem. 39 1109-1112.

DEGGER N, WEPENER V, RICHARDSON BI and WU RSS (2011) Brown mussels (Perna perna) and semipermeable membrane devices (SPMDs) as indicators of organic pollutants in the South African marine environment. Mar. Pollut. Bull. 63 91-97.

EKPO BO, FUBARA FB, EKPA OD and MARYNOWSKI HL (2012) Determination of hydrocarbon sources using n-alkane and $\mathrm{PAH}$ distribution indices in sediments from coastal areas of Bonny River in Niger delta, Nigeria. ARPN J. Earth Sci. 1 9-20.

HARDING WR, THORNTON JA, STEYN G, PANUSKA J and MORRISON IR (2004) Hartebeespoort Dam Remediation Project (Phase 1) Volume 1 Action Plan. Department of Agriculture, Environment and Tourism of the North West Province Government (DACET, NWP), South Africa.

HUCKINS JN, MANUWEERA GK, PETTY JD, MACKAY D and LEBO JA (1993) Lipid-containing semipermeable membrane devices for monitoring organic contaminants in water. Environ. Sci. Technol. 27 2489-2496.

HUCKINS JN, PETTY JD and BOOIJ K (2006) Monitors of Organic Chemicals in the Environment: Semipermeable Membrane Devices. Springer, New York. 
HUCKINS JN, PETTY JD, LEBO JA, ALMEIDA FV, BOOIJ K, ALVAREZ DA, CRANOR WL, CLARK RC and MOGENSEN BB (2002) Development of the permeability/performance reference compounds approach for in situ calibration of semipermeable membrane devices. Environ. Sci. Technol. 36 85-91.

KOT A, ZABIEGALA B and NAMIESNIK J (2000) Passive sampling for long-term monitoring of organic pollutants in water. Trends Anal. Chem. 19 (7) 446-459.

LANDRUM PF, REINHOLD MD, NIHART SR and EADIE BJ (1985) Predicting the bioavailability of organic xenobiotics to Pontoporeia hoyi in the presence of humic and fluvic materials and natural dissolved organic matter. Environ. Toxicol. Chem. 4 459-467.

LEVINSON J, CHANNSLUSZNY S, YASMAN Y, BUTALOV V and SCHETCHER I (2008) Detector for particulate PAHs in water. Anal. Bioanal. Chem. 381 1884-1591.

MAYER P, TOLLS J, HERMENS L and MACKAY D (2003) Equilibrium sampling devices. Environ. Sci. Technol. 37 184A-191A.

NIEUWOUDT C, PIETERS R, QUINN L, KYLIN H, BORGEN AR and BOUWMAN H (2011) Polycyclic aromatic hydrocarbons (PAHs) in soil sediment from industrial, residential, and agricultural areas in central South Africa: An initial assessment. Soil Sediment Contam. 20 188-204.

NYONI H, CHIMUKA L, VRANA B and CUKROWSKA E (2011) Membrane assisted passive sampler for triazines compounds-characterisation of environmental conditions and field performance. Anal. Chim. Acta 694 (1-2) 75-82.

OGATA H, TAKADA K, MIZUKAWA H, HIRAI S, IWASA S, ENDO Y, MATO M, SAHA K, OKUDA A, NAKASHIMA M, MURAKAMI N, ZURCHER R, BOOYATUMANONDO MP, ZAKARIA LQ, DUNG C, MIQUEZ MM, GORDON S, SUZUKI C, MOORE HK, KARAPANAGIOTI T, MCCLURG S, WEERTS E, BURRES W, SMITH M, VAN VELKENBURG JS, LANG RC, LANG D, LAURSEN B, DANNER N, STEWARDSON RC and THOMPSON T (2009) International pellet watch: Global monitoring of persistent organic pollutants (POPs) in coastal waters. 1. Initial phase data on PCBs, DDTs and HCHs. Mar. Pollut. Bull. 58 1437-1446.

QUINN L, PIETERS R, NIEUWOUDT C, BORGEN AR, KYLIN H and BOUWMAN H (2009) Distribution profiles of selected organic pollutants in soils and sediments of industrial, residential and agricultural areas of South Africa. J. Environ. Monit. 11 1647-1657.

RUSINA T, SMEDES F, KOBLIZKOVA M and KLANOVA J (2010) Calibration of silicone rubber passive samplers: experimental and modelled relations between sampling rate and compound properties. Environ. Sci. Technol. 44 362-367.
SABALIUNAS D and SODERGREN A (1997) Use of semipermeable membrane devices to monitor pollutants in water and assess their effects: a laboratory test and field verification. Environ. Pollut. 96 (2) 195-205.

STOCKHOLM CONVENTION (2007) Stockholm Convention on Persistent Organic Pollutants (POPs). URL: http://chm.pops.int (Accessed November 2013).

TIEMANN U (2008) In vivo and in vitro effects of the organochlorine pesticides DDT, TCPM, methoxychlor, and lindane on the female reproductive tract of mammals: a review. Reprod. Toxicol. 25 (3) 316-326.

VAN REI WF (1987) The Hartbeespoort dam - a magnet to millions? In: Thornton JA and Walmsley RD (eds.) Hartbeespoort Dam Quo Vadis. FRD Ecosystem Programmes Occasional Report Vol. 25. 83-93.

VERWEIJ F, BOOIJ K, SATUMALAY K, VAN DER MOLEN N and VAN DER OOST R (2004) Assessment of bioavailable PAH, PCB and OCP concentrations in water, using semipermeable membrane devices (SPMDs), sediments and caged carp. Chemosphere 54 1675-1689.

VRANA B, MILLS GA, ALLAN IJ, DOMINIAK E, SVENSSON K, MORRISON G and GREENWOOD R (2005) Passive sampling techniques for monitoring pollutants in water. Trends Anal. Chem. 24 845-868.

VRANA B, PASCHKE A, POPP P and SCHUURMANN G (2001) Use of semipermeable membrane devices (SPMDs): determination of bioavailable, organic, waterborne contaminants in the industrial regions of Bitterfield, Saxony-Anhalt, Germany. Environ. Sci. Pollut. Res. 8 27-34.

VRANA B, KLUCAROVA V, BENICKA E, ABOU-MRAD N, AMDANY R, HORAKOVA S, DRAXTER A, HUMER F and GANS O (2014) Passive sampling: An effective method for monitoring seasonal and spatial variability of dissolved hydrophobic organic contaminants and metals in the Danube River. Environ. Pollut. 184 101-102.

WANG J, BI Y, PFISER G, HENKELMANN B, ZHU K and SCHRAMM KW (2009) Determination of PAH, PCB and OCP in water from the Three Gorges Reservoir accumulated by semipermeable membrane devices (SPMD). Chemosphere 75 1119-1127.

WILLET KL, ULRICH EM and HITES RA (1998) Differential toxicity and environmental fate of hexachlorocylohexane isomers. Environ. Sci. Technol. 32 2197-2207.

ZHANG ZL, HUANG J, YU G and HONG HS (2004) Occurrence of PAHs, PCBs and organochlorine pesticides in the Tonghui River of Beijing, China. Environ. Pollut. 130 249-261. 


\section{APPENDIX}

\begin{tabular}{|c|c|c|c|c|}
\hline \multicolumn{5}{|c|}{$\begin{array}{l}\text { TABLE A1 } \\
\begin{array}{c}\text { Details of characteristic ions ( } \mathrm{m} / \mathrm{z} \text { values) used in the analysis of polycyclic aromatic } \\
\text { hydrocarbons in single ion monitoring (SIM) mode by GC/MS }\end{array}\end{array}$} \\
\hline Compound & \begin{tabular}{|c}
$\begin{array}{c}\text { Retention time } \\
\text { (min) }\end{array}$ \\
\end{tabular} & ${ }^{1} \mathrm{~m} / \mathrm{z} 1$ & $\mathrm{~m} / \mathrm{z} 2$ & $\mathrm{~m} / \mathrm{z} 3$ \\
\hline${ }^{2}$ Terphenyl & 23.04 & 230 & 215 & 202 \\
\hline Naphthalene & 8.37 & 128 & 129 & 126 \\
\hline Biphenyl & 10.48 & 154 & 153 & 155 \\
\hline Acenaphthylene & 11.49 & 152 & 153 & 150 \\
\hline Acenaphthene & 11.91 & 154 & 153 & 155 \\
\hline Fluorene & 13.3 & 166 & 167 & 164 \\
\hline Phenanthrene & 16.42 & 178 & 179 & 176 \\
\hline Anthracene & 16.61 & 178 & 179 & 176 \\
\hline Fluoranthene & 21.13 & 202 & 203 & 200 \\
\hline Pyrene & 22.09 & 202 & 203 & 200 \\
\hline Retene & 23.46 & 219 & 234 & 205 \\
\hline Benzo[b]fluorene & 23.9 & 216 & 215 & 217 \\
\hline Benzonaphthothiophene & 26.39 & 234 & 235 & 232 \\
\hline Benzo[ghi]fluoranthene & 26.58 & 226 & 227 & 224 \\
\hline Cyclopenta[cd]pyrene & 27.45 & 226 & 227 & 224 \\
\hline Benzo[a]anthracene & 27.49 & 228 & 229 & 226 \\
\hline Triphenylene & 27.6 & 228 & 229 & 226 \\
\hline Chrysene & 27.66 & 228 & 229 & 226 \\
\hline Benzo[b]fluoranthene & 32.17 & 252 & 253 & 250 \\
\hline Benzo[j]fluoranthene & 32.18 & 252 & 253 & 250 \\
\hline Benzo[k]fluoranthene & 32.29 & 252 & 253 & 250 \\
\hline Benzo[e]pyrene & 33.27 & 252 & 253 & 250 \\
\hline Bezno[a]pyrene & 33.48 & 252 & 253 & 250 \\
\hline Perylene & 33.8 & 252 & 253 & 250 \\
\hline Indeno[123cd]pyrene & 38.39 & 276 & 277 & 274 \\
\hline Dibenzo[ah]anthracene & 38.51 & 278 & 279 & 276 \\
\hline Dibenzo[ac]anthracene & 38.52 & 278 & 279 & 276 \\
\hline Benzo[ghi]perylene & 39.7 & 276 & 277 & 274 \\
\hline Anthanthrene & 40.41 & 276 & 277 & 274 \\
\hline Coronene & 50.13 & 300 & 301 & 298 \\
\hline${ }^{3} \mathrm{D}_{8}$-Naphthalene & 8.37 & 136 & 137 & 134 \\
\hline${ }^{3} \mathrm{D}_{10}$-Phenanthrene & 16.33 & 188 & 189 & 184 \\
\hline${ }^{3} \mathrm{D}_{12}$-Perylene & 33.69 & 264 & 265 & 260 \\
\hline
\end{tabular}

${ }^{1}$ The ion in the first column was used for quantification, the other two were used as qualifier ions to confirm compound identity

${ }^{2}$ Instrumental internal standard

${ }^{3}$ Recovery internal standard 


\begin{tabular}{|l|c|c|c|}
\hline $\begin{array}{c}\text { TABLE A2 } \\
\text { Details of characteristic MRM transitions (m/z values of parent and daughter ion } \\
\text { are given) used in the analysis of PCBs and OCPs by GC/MS/MS }\end{array}$ \\
\hline Name & $\begin{array}{c}\text { Retention time } \\
\text { (min) }\end{array}$ & $\begin{array}{c}\text { 'MRM transition } \\
\text { (Quantifcation) }\end{array}$ & $\begin{array}{c}\text { MRM } \\
\text { transition } \\
\text { (Qualifier) }\end{array}$ \\
\hline${ }^{2}$ PCB 121 & 20.24 & $325.9>255.9$ & $327.9>255.9$ \\
\hline${ }^{3}$ PCB 30 & 17.2 & $256>186$ & $258>186$ \\
\hline${ }^{3}$ PCB 185 & 27.28 & $393.8>323.9$ & $395.8>325.9$ \\
\hline PCB 28 & 17.13 & $256>186$ & $258>186$ \\
\hline PCB 52 & 18.15 & $289.9>220$ & $291.9>220$ \\
\hline PCB 101 & 21.05 & $325.9>255.9$ & $327.9>255.9$ \\
\hline PCB 118 & 23.27 & $325.9>255.9$ & $327.9>255.9$ \\
\hline PCB 153 & 23.95 & $359.8>289.9$ & $361.8>289.9$ \\
\hline PCB 138 & 24.91 & $359.8>289.9$ & $361.8>289.9$ \\
\hline PCB 180 & 27.22 & $393.8>323.9$ & $395.8>325.9$ \\
\hline PeCB & 11.85 & $250>215$ & $252>215$ \\
\hline HCB & 14.52 & $283.8>248.9$ & $285.8>213.8$ \\
\hline a-HCH & 14.31 & $219>183$ & $181>145$ \\
\hline$\beta$-HCH & 15.1 & $219>183$ & $181>145$ \\
\hline$\gamma-H C H$ (Lindane) & 15.29 & $219>183$ & $181>145$ \\
\hline$\delta-H C H$ & 16.19 & $219>183$ & $181>145$ \\
\hline o,p'-DDE & 20.89 & $246>176$ & $318>248$ \\
\hline p,p'-DDE & 22.01 & $246>176$ & $318>248$ \\
\hline o,p'-DDD & 22.27 & $235>165$ & $237>165$ \\
\hline p,p'-DDD & 16.45 & $235>165$ & $237>165$ \\
\hline o,p'-DDT & $23.59>165$ & $237>165$ \\
\hline p,p'DDT & $235>165$ & $237>165$ \\
\hline$\varepsilon-H C H$ & $181>145$ & $219>183$ \\
\hline
\end{tabular}

${ }^{1}$ The MRM transition in the first column was used for quantification, the other was used to confirm compound identity

${ }^{2}$ Instrumental internal standard

${ }^{3}$ Recovery internal standard 